\title{
CLOSED CYCLE OF AIR-STEAM MIXTURE IN THE DRYING SECTION OF PAPER MACHINE
}

\author{
V.G. Kazakov, E.N. Gromova
}

\author{
Higher School of Technology and Energy of St. Petersburg State University of Industrial \\ Technologies and Design, St. Petersburg, Russia \\ gromova.gturp@mail.ru
}

\begin{abstract}
The energy efficiency of the drying section of paper machine is determined by the technology of heat flows arrangements in it. Paper drying is the most energy-consuming stage of paper production. The thermal mode of the drying section is provided by the steam condensate system which is a part of it. Analysis of exergy increments shows that almost all elements of the drying thermal process are characterized by low exergy efficiency. The main ways for increasing the degree of thermodynamic perfection of the processes occurring in the drying section of the paper machine are identified based on the exergy analysis. It is assumed that the deep internal heat recovery of the steam-air mixture for heating the source air will increase the exergy efficiency of the heat recovery plant and reduce heat removal to the environment. The effectiveness of development and implementation of a closed cycle use of steam-air mixture in the drying section was examined. Building a closed cycle provides that the air mainly has a process duty, that is, it is a transport agent for the transfer of moisture and heat along a closed circuit. The calculations show that the exergy efficiency of the processes in the recovery unit of the drying section of the paper machine of the existing production is $28.6 \%$ against $66.29 \%$ for the proposed method.
\end{abstract}

Keywords: paper machine, paper drying, exergy analysis, energy saving, exergy efficiency, ventilation systems with heat recovery, heat exchanger, exergy, process ventilation, paper production, heat recovery, energy efficiency.

For citation: Kazakov VG, Gromova EN. Closed cycle of air-steam mixture the drying section of paper machine. Power engineering: research, equipment, technology 2019; 21(3):24-31. (In Russ). doi:10.30724/1998-9903-2019-21-5-6-24-31.

\section{ЗАМКНУТЫЙ ЦИКЛ ПАРОВОЗДУШНОЙ СМЕСИ В СУШИЛЬНОЙ ЧАСТИ БУМАГОДЕЛАТЕЛЬНОЙ МАШИНЫ}

\author{
В.Г. Казаков, Е.Н. Громова \\ Высшая школа технологии и энергетики Санкт-Петербургского \\ государственного университета промышленных технологий и дизайна, \\ г. Санкт-Петербург, Россия \\ gromova.gturp@mail.ru
}

Резюме: Энергетическая эффективность бумагоделательной машины определяется технологией организации тепловых потоков в ее сушильной части. Сушка бумаги является наиболее энергетически затратным этапом производства бумажной продукции, так как наибольшее количество водяных паров выделяется именно в сушильной части БДМ. 
Рациональное распределение потоков воздуха и паровоздушной смеси в сушильной части способствует повышению производительности и стабилизации работы машины.

Литературный обзор. Тепловой режим сушильной части обеспечивается входящей в её состав пароконденсатной системой. Сущуествующие системы теплоснабжения с каскадным распределением давления, в состав которых входят, как правило, двухступенчатые теплорекуперационные установки позволяют частично утилизировать низкопотенциальную теплоту отработавщего пара и сушильного воздуха.

Материаль и методы: Авторами были произведены расчеты сушильной части действующей бумагоделательной машины. Распределение энергии по функциональным частям БДМ в случае традиичонной технологической схемы позволяет сделать следующий вывод: при незначительной доле удаляемой влаги в суиильной части БДМ (0,7 \%), потребление энергии здесь максимально. Анализ приращений эксергии показывает, что практически все элементы теплового процесса сушки характеризуются низкими значениями эксергетических КПД. На основании эксергетического анализа в статье выделяются основные направления повышения степени термодинамического совериенства технологического процесса в сушильной части бумагоделательной машинь.

Результаты и обсуждение: Предполагается, что глубокая внутренняя регенерация теплоты паровоздушной смеси для нагрева исходного воздуха позволит увеличить эксергетический КПД теплорекуперационной установки и снизить отвод теплоть в окружающую среду. Рассматривается эффективность разработки и реализации замкнутого ичикла использования паровоздушной смеси в сушильной части. Организация замкнутого цикла предусматривает, что воздух, в основном, несет технологическую нагрузку, то есть является транспортным агентом в переносе влаги и теплоты по замкнутому контуру.

Выводы: Проведенные расчеты показывают, что эксергетический КПД прочессов в рекуперационной установке сушильной части бумагоделательной машинь действующих производств составляет 28,6\% против 66,29\% в предложенном способе. В целом, эксергетический КПД суиильной части БДМ в случае реализации замкнутого циклла паровоздушной смеси будет равен $72,4 \%$.

Ключевые слова: бумагоделательная машина; сушка бумаги; эксергетический анализ; энергосбережение; эксергетический КПД; системы вентиляции с рекуперацией теплоты, теплорекуператор; эксергия; технологическая вентиляция; производство бумаги; утилизация теплоты;; энергетическая эффективность.

\section{Introduction}

The energy efficiency of a paper machine (PM) is largely determined by the technology for heat flows arrangement in the drying section.

Modern paper machines are equipped with rather complex and high-performance ventilation systems and installations that ensure successful running of the paper manufacturing process. Along the entire paper motion from the headbox to the reel the necessary thermo-humid regime of the air surrounding the paper sheet is created using ventilation systems. PM includes wire, press and drying sections. The wire section is designed to remove the main part of moisture and formation of the paper web, the press part is aimed at removing the additional moisture by pressing. The remaining part of moisture is removed by drying in the drying section of the machine [1].

A large amount of moisture is released from the surface of the wet web. Ventilation units are used to remove the forming water vapors from the wire section outside the hall. At the same time, their condensation on the surrounding surfaces is prevented, and the necessary sanitary conditions for the staff are created. The highest water vapor emissions occur in the drying section 
of the machine. The supply and removal of heat in this part of PM determines the heat consumption from external sources. That is why the drying section has long been the object of close attention of scientists and engineers as the object of the greatest expenditure of thermal energy.

Ensuring the necessary parameters of the air environment is achieved by the arranged supply of fresh and exhaust air.

The rational distribution of air flows, the optimal choice of parameters and the frequency of air exchange in the drying section contribute to increased productivity and stabilization of the machine operation, alignment of the moisture profile of the paper web.

\section{Literature review}

The thermal regime of the drying section is provided by the steam condensate system which is a part of it. Currently, the group heat supply system with cascade pressure distribution and steam bypass over individual groups of cylinders has gained predominant use. Such a heat supply system prevents the passage of steam into the condensate system [2,3].

The thermal circuit of the drying section consists of three functional groups: drying cylinders, water separators and heat recovery unit. A heat recovery unit is an integral part of the existing paper machines and includes three units, each of which consists of two recovery stages (heat exchangers) and a scrubber for heating the process water. The first stage of recovery provides pre-heating of the process (drying) air, the second one provides heating of the outside (ventilation) air. Thus, the low-grade heat of the exhaust steam and the drying air is partially used. From the press section of the machine, the wet paper web enters the first paper dryer cylinder. After passing 46 drying cylinders, $92 \%$ of the paper web dried to dryness is removed from the drying section for further processing.

From under the hood cap of the PM drying section the air-steam mixture 1 (Fig. 1) with a temperature of $100{ }^{\circ} \mathrm{C}$ is fed into the first recovery stage 2 (TU-1). The air-steam mixture gives some part of heat to the process (drying) air 17 supplied from the machine room with a temperature of $28^{\circ} \mathrm{C}$, and heats it up to $42^{\circ} \mathrm{C}$. Drying air from the recovery stage 2 is fed into the air heater 12 by centrifugal fan 8 , where it is heated to $100{ }^{\circ} \mathrm{C}$, and after it is sent under the hood cap of the drying section of the machine 14 .



Fig. 1. Technological scheme of a traditional heat recovery unit:

1 - air-steam mixture; 2 - heat exchanger (heat trap) TU1;

3 - heat exchanger (heat trap) TU2; 4 - outside air;

5 - scrubber; 6 - axial fan; 7 - shutoff valve;

8 - air heater; 9 - centrifugal fan; 10 - check valve;

11 - ventilation air; 12 - air heater; 13 - steam; 14 - drying air;

15 - condensate; 16 - scrubber water and condensate from the exhaust air;

17 - air supplied from the machine room

Condensate 15 is discharged to the CHP, and scrubber water 16 is used to dilute the paper 
pulp. Outside air in the winter period is heated in the second recovery stage 3 up to temperature of $0{ }^{\circ} \mathrm{C}$, and then it is heated to $20^{\circ} \mathrm{C}$ in a heater 8 by steam from the thermal power plant. From the heater 8 , the heated air is supplied to the machine hall 11 , where it assimilates the heat of equipment and reaches temperature of $28^{\circ} \mathrm{C}$, at which it enters the first recovery stage 2 .

The partially cooled air-steam mixture flows from the first recovery stage 2 (TU-1) to the second recovery stage 3 (TU-2), where it gives some part of its heat (up to the saturation temperature) to the outside air 4 . Next, the air-vapor mixture enters the scrubber 5 . The purpose of the scrubber is to separate moisture from the steam-air mixture by cooling it. The steam in it condenses. The temperature of the air discharged from the scrubber is $45^{\circ} \mathrm{C}$.

\section{Materials and methods}

The authors have calculated the drying section of the existing paper machine.

The drying section of the paper machine under consideration consists of 46 paper drying and one refrigerating cylinders. The drying cylinders are arranged in two rows, staggered, and are heated by condensing steam. Its dryness before drying is $43.5 \%$, final dryness of paper is $92 \%$. The temperature of the pulp after the wire frame is $50{ }^{\circ} \mathrm{C}$. The consumption of drying air is $12 \mathrm{~kg}$ per $1 \mathrm{~kg}$ of evaporated water. The productivity is 13.1 tons of paper per hour.

Energy supply and dehumidification for various parts of PM are given in table 1.

Table 1

Energy distribution at PM

\begin{tabular}{|c|l|c|c|c|c|c|c|}
\hline \multirow{2}{*}{ No. } & Characteristics & \multicolumn{2}{|c|}{ Wire section } & \multicolumn{2}{c|}{ Press section } & \multicolumn{2}{c|}{ Drying section } \\
\cline { 3 - 8 } & Driver & $\begin{array}{c}\text { Vacuum- } \\
\text { pumps }\end{array}$ & Driver & $\begin{array}{c}\text { Vacuum- } \\
\text { pumps }\end{array}$ & $\begin{array}{c}\text { Electrical } \\
\text { energy }\end{array}$ & Steam \\
\hline 1 & $\begin{array}{l}\text { Energy } \\
\text { distribution, \% }\end{array}$ & 6 & 5 & 6 & 11 & 3 & 69 \\
\hline 2 & $\begin{array}{l}\text { Removed } \\
\text { moisture, } \%\end{array}$ & \multicolumn{2}{|c|}{97.2} & \multicolumn{2}{|c|}{2.1} & \multicolumn{2}{|c|}{0.7} \\
\hline
\end{tabular}

Analysis of the results given in table 1 shows that only $0.7 \%$ of the total moisture removed in the paper machine is removed in the drying section of the machine. The amount of energy consumed to remove this moisture is $72 \%$ of the total energy supplied, of which $69 \%$ is energy consumption in the form of low pressure steam.

From table 1 it can also be concluded that, despite the relatively small amount of moisture removed in the drying section of the PM $(0.7 \%)$, the energy consumption here is maximum, and the amount of heat input in the form of saturated steam from the CHP is determined by this particular section of PM.

During the study of the drying section of the existing paper machine it was established [4] that its exergy efficiency is only $52.6 \%$. The low exergy efficiency of the drying section is determined by the exergy efficiency of the heat recovery unit of the drying section $(57.5 \%)$ with the spent exergy amounted to $30 \%$ of the total exergy supplied.

This process is characterized by high irreversibility and, accordingly, low exergy efficiency. Analysis of the components of the exergy balance made it possible to identify the main directions for increasing the degree of thermodynamic perfection of the technological process in the drying section of PM.

1. Increasing the exergy efficiency of the heat recovery unit. Analysis of the exergy balance items shows that the exergy efficiency and the share of exergy spent in this process to the total exergy in the system are: $\eta=57.5 \%$ and $\gamma=30 \%$, respectively.

2. Reducing the heat flux discharged into the environment. As it follows from the heat balance, $60 \%$ of the heat flux is removed to the environment.

3 . Increasing the potential of the drying air during the process of its absorption of the steam of the PM drying part.

4. Increasing the dryness of the paper web entering the dryer. 
The practical implementation of the modernization of the drying section of PM in these areas becomes possible on the ground of the development of the following technical solutions [5, 6]:

- Intensification of the work of heat exchangers with a corresponding reduction in underheating between the heated air and the steam-air mixture (SAM). This measure will increase the exergy efficiency of the heat recovery unit;

- Development of a closed or almost closed SAM cycle of the PM drying section;

- Application of heat pump units in the PM ventilation system [7];

- Increasing the potential of drying air by optimizing the temperature of air directed under the PM cap, and the temperature of the source air [8];

The proposed technical solutions are not exhaustive. They can be considered as possible options for the modernization of the PM drying section.

\section{Results and discussion}

In this article, the authors considered one of the most promising ways to increase the exergy efficiency of the PM drying section, which also allows one to reduce energy costs in the steamcondensate system of the existing plants, namely the development of a closed cycle of a steam-air mixture.

Fig. 2 shows a scheme of a heat recovery unit of a paper machine with a closed drying air cycle.



Fig. 2. The ventilation scheme of the drying section of the paper machine with a closed cycle of the drying air motion: 1 - closed hood over the drying part; 2 - air heater; 3 - aftercooler; 4 - mixing heat exchanger (MHE); 5 - centrifugal fan circulating air in a closed hood (drying chamber); 6 - moisture, removed from paper web during contact drying

The air-steam mixture (Fig. 2) with a temperature of $100{ }^{\circ} \mathrm{C}$, removed from under the insulated hood 1 that covers the drying section of the machine (drying chamber), is sent to the heat exchanger TU 2 .

The air-steam mixture leaves the TU 2 heat exchanger at a saturation temperature of $45^{\circ} \mathrm{C}$ and is sent to the mixing heat exchanger - aftercooler 3 , from where, at a temperature of $25{ }^{\circ} \mathrm{C}$, dried and cooled, the air returns to TU 2. Some part of the dried air, equal to the mass of cold air, used in the mixing heat exchanger is removed to the hall of the paper machine. In the heat exchanger $\mathrm{TU} 2$, the air is heated to $80{ }^{\circ} \mathrm{C}$, then it enters the air heater $(\mathrm{AH}) 4$, where its temperature rises to $100{ }^{\circ} \mathrm{C}$, i.e. the temperature necessary for the ventilation process of the considered drying unit $[9,10]$.

In the aftercooler, the air temperature decreases due to the addition of outside air with an average annual temperature of $7{ }^{\circ} \mathrm{C}$. In summer, a cooling machine is used [11].

Moisture released from the web during contact drying is absorbed by the drying air and removed from heat exchangers $[12,13]$. All the heat released during condensation of the heating 
steam in the cylinders, besides the heat carried away by the heated paper web, is absorbed by air and is used in heat exchangers of the regenerative circuit 2 and 3 . The air is circulated by a centrifugal fan 5 .

The thermodynamic process carried out in the proposed heat recovery unit is shown in Fig. 3 as an $i-d$ diagram.

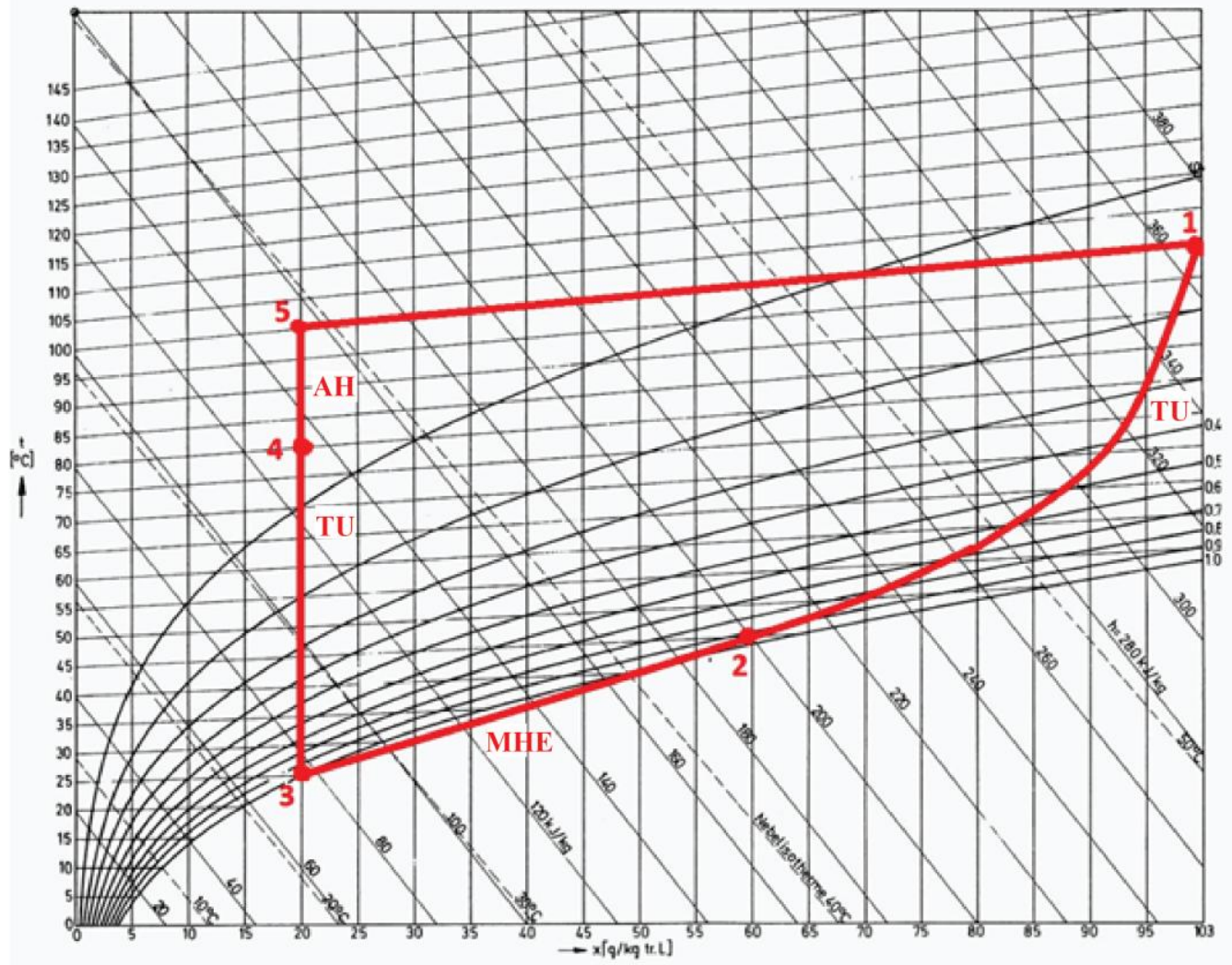

Fig. 3. Thermodynamic process of ventilation of the drying section of the machine for a closed cycle of air movement

The diagram (Fig. 3) shows the following processes:

1-2 - Cooling of the drying (technological) air in the heat exchanger TU to $45^{\circ} \mathrm{C}, d=60$ $\mathrm{g} / \mathrm{kg}$ of dry air;

2-3 - Cooling of the drying (technological) air in the aftercooler;

3-4 - Heating of dried and cooled air in a heat exchanger TU to $80^{\circ} \mathrm{C}, \mathrm{d}=20 \mathrm{~g} / \mathrm{kg}$ of dry air;

4-5 - Heating of the dried air in the heater $\mathrm{t}=100^{\circ} \mathrm{C}$;

5-1 - Change of air parameters in the drying chamber $\mathrm{t}=100^{\circ} \mathrm{C}, \mathrm{d}=103 \mathrm{~g} / \mathrm{kg}$ of dry air.

Exergy characteristics of the thermal process of heat and moisture transport by the proposed method are given in table. 2 .

Analysis of thermal processes of functional groups by the proposed method shows that exergy efficiency is quite high $[14,15]$. So the processes in the heat exchanger of the regenerative circuit and the heater, where $91 \%$ of the exergy of the total in the system is supplied, are characterized by exergy efficiency of $73.73 \%$ and $63.60 \%$, respectively. 
Table 2

Exergy characteristics of the heat recovery unit of the PM drying section for a closed cycle of drying air

\begin{tabular}{|c|c|c|c|}
\hline Exergy characteristics & $\begin{array}{c}\text { Regenerative circuit heat } \\
\text { exchanger }\end{array}$ & Aftercooler & Air heater \\
\hline Heat flow, $\Delta Q_{i}, \mathrm{~kW}$ & 2947.98 & 1071.99 & 1071.99 \\
\hline $\begin{array}{c}\text { Thermodynamic heating } \\
\text { temperature, } T_{\mathrm{H} i}, \mathrm{~K}\end{array}$ & 325.5 & 289 & 363 \\
\hline $\begin{array}{c}\text { Received exergy, } \\
\Delta E_{\mathrm{H} i}, \mathrm{~kW}\end{array}$ & 412.08 & 33.38 & 245.11 \\
\hline $\begin{array}{c}\text { Thermodynamic cooling } \\
\text { temperature, } T_{\mathrm{O} i}, \mathrm{~K}\end{array}$ & 345.5 & 308 & 437.17 \\
\hline $\begin{array}{c}\text { Spent exergy, } \\
\Delta E_{\mathrm{O} i}, \mathrm{~kW}\end{array}$ & 558.88 & 97.45 & 385.4 \\
\hline $\begin{array}{c}\text { Exergy efficiency, } \\
\eta_{i}=\Delta E_{\mathrm{H} i} / \Delta E_{\mathrm{O} i}, \%\end{array}$ & 73.73 & 34.26 & 63.60 \\
\hline
\end{tabular}

Thus, the exergy efficiency of processes in the recovery unit of the existing PM drying sections is $28.6 \%$ versus $66.29 \%$ for the proposed method.

\section{Conclusions}

Analysis of the exergy characteristics of the PM drying section during the implementation of the proposed method for heat arrangement in a heat recovery unit allows us to draw the following conclusions.

The smallest exergy efficiency have the third group of drying cylinders $(59.6 \%)$, air heater $(63.6 \%)$ and terminal cooler (34.3\%). However, the total share of spent exergy in them is about $12 \%$ of the total spent exergy. Therefore, their influence on the overall efficiency of the PM drying section is not significant. In general, the exergy efficiency of PM drying section is $72.4 \%$. As was indicated above [4], the exergy efficiency of the PM drying section for the existing modern plants is $52.6 \%$. Such a significant increase in exergy efficiency was achieved by scientifically based heat technology in a heat recovery unit with a closed cycle of air movement.

\section{References}

1. Boykov LM. Energosberezhenie i uskorenie sushki bumagi i kartona. SPb.: SPbGUPTD, 2018.

2. Boykov LM, Prokhorov DA, Ionin EN. Modernizaciya sistem ventilyacii na predpriyatiyah CBP. Cellyuloza, bumaga, karton. 2015. Vol. 10.

3. Dincer I, Rosen MA. Exergy Analysis of Heating, Refrigerating and Air Conditioning: Methods and Applications.Elsevier Inc, J. Exergy 2015, 18 (2): 129. doi: 10.1016 / c2013-0-06800-4

4. Mateos-Espejel E, Paris J, Savulescu L, Maréchal F. Unified methodology for thermal energy efficiency improvement; application to kraft process. Chemical Engineering Science. 2011, 2 (66). doi: 10.1016 / j.ces.2010.09.032.

5. Belsky AP, Lotvinov MD. Ventilyaciya bumagodelatel'nyh mashin. M.:Lesnaya promyshlennost', 1990.( In Russ).

6. Brodyansky VM. Eksergeticheskij metod i ego prilozheniya. M.: Energoatomizdat, 1988. 7

\section{Литература}

1. Бойков Л.М. Энергосбережение и ускорение сушки бумаги и картона. СПб.: СПбГУПТД: Высш. шк. технологии и энергетики 2018. - 258c

2. Бойков Л.М., Прохоров Д.А., Ионин Е.Н. Модернизация систем вентиляции на предприятиях ЦБП // Целлюлоза, бумага, картон. 2015. №10.

3. Dincer I., Rosen M.A. Exergy Analysis of Heating, Refrigerating and Air Conditioning: Methods and Applications. Elsevier Inc, 2015//J. Exergy., 2015. Vol. 18, № 2.pp129.

4. Mateos-Espejel E., Paris J., Savulescu L., Maréchal F. Unified methodology for thermal energy efficiency improvement; application to kraft process. // Chemical Engineering Science. 2011. V. 66, N 2.

5. Бельский А.П., Лотвинов М.Д. Вентиляция бумагоделательных машин. М.: Лесная промышленность, 1990.

6. Бродянский В. М. Эксергетический метод и 
7. Kurov VS. Bumagodelatel'nye $i$ kartonodelatel'nye mashiny. SPb: SPbPU: 2008. (In Russ).

8. Bojkov LM. Ventilyaciya bumago- $i$ kartonodelatel'nyh mashin. SPb.: SPbGUPTD, 2018.(In Russ).

9. Sukhodub IO, Deshko VI. Eksergeticheskij analiz sistem ventilyacii s utilizaciej polnoj teploty // Inzhenerno-stroitel'nyj zhurnal. 2014; 46 (2): 36-46 (In Russ). doi: 10.5862/MCE.46.5.

10. Hovey G, Allen DG, Tran H. Drying kinetics of biosludge from pulp and paper mills.Pulping, engineering, environmental, recycling, sustainability conferenceJacksonville, FL: TAPPI Press, 2019. 2730 Oct 2019.

11. Nemirovskaya VV, Kuzovlev VA. Energosberezhenie $\mathrm{s}$ primeneniem utilizatorov teploty. Nauchnyj zhurnal NIU ITMO. Seriya: Holodil'naya tekhnika i kondicionirovanie. 2015. N2 (In Russ).

12. Plaznik U, Poredoš A, Kitanovski A, Vrabelj M, Kutnjak Z, et al. Electrocaloric cooling; the importance of electric-energy recovery and heat regeneration EPL. 2015. Vol. 111. (5). (In Russ). Available at :https://doi.org/10.1209/02955075/111/57009.

13. Gjennestad MA, Aursand E, Magnanelli E, et al. Perfomance analysis of heat and energy recovery ventilators using exergy analysis and nonequilibrium thermodynamics. Energy and Buildings. 2018. Vol.170. doi:10.1016/j enbuild 2018.04.013

14. Kazakov VG, Lukanin PV, Smirnova OS. Eksergeticheskij analiz tekhnologicheskih skhem proizvodstva cellyulozy i bumagi // Promyshlennaya teploenergetika. 2009. № 11.

15. Mikhailov VA, Sotnikova EV, Kalpina NYu. Energosberezhenie $v$ sistemah ventilyacii $i$ kondicionirovaniya vozduha. M. Ser. Nauchnaya mysl'. 2017.(In Russ). его приложения. М.: Энергоатомиздат, 1988г.

7.В.С.Куров. Бумагоделательные и картоноделательные машины /. Под ред. В.С. Курова, Н.Н. Кокушина. СПб: Изд-во СПбПУ, 2008.

8 Бойков Л.М. Вентиляция бумаго- и картоноделательных машин. СПб.: СПбГУПТД, 2018.

9. Суходуб И.О., Дешко В.И. Эксергетический анализ систем вентиляции с утилизацией полной теплоты // Инженерно-строительный журнал. 2014. №2 (46).

10. Hovey G., Allen D.G., Tran H. Drying kinetics of biosludge from pulp and paper mills.Pulping, engineering, environmental, recycling, sustainability conference;. Jacksonville.FL: TAPPI Press, 2019 Ссылка активна на :27-30 октября 2019.

11.Немировская В.В., Кузовлев А.В. Энергосбережение с применением утилизаторов теплоты // Научный журнал НИУ ИТМО. Серия: Холодильная техника и кондиционирование. 2015. № 2

12. Plaznik U., Poredoš A., Kitanovski A., Vrabelj M., Kutnjak Z., Malič B. Electrocaloric cooling; the importance of electric-energy recovery and heat regeneration // EPL. 2015. Vol. 111. N 5.

13. Gjennestad M.A., Aursand E., Magnanelli E., et al. Perfomance analysis of heat and energy recovery ventilators using exergy analysis and nonequilibrium thermodynamics // Energy and Buildings. 2018. Vol. 170.

14. Казаков В.Г., Луканин П.В., Смирнова О.С. Эксергетический анализ технологических схем производства целлюлозы и бумаги // Промышленная теплоэнергетика. СПб ГТУРП. СПб. 2013.-с 93 . № 11.

15. Михайлов В.А., Сотникова Е.В., Калпина Н.Ю. Энергосбережение в системах вентиляции и кондиционирования воздуха. М. Сер. Научная мысль. 2017.

\section{Authors of the publication}

Vladimir G. Kazakov - Department of Industrial Heat Power Engineering of the Higher School of Technology and Energy of St. Petersburg State University of Industrial Technologies and Design.

Ekaterina N. Gromova - Department of Industrial Heat Power Engineering of the Higher School of Technology and Energy of St. Petersburg State University of Industrial Technologies and Design. 